\title{
The Influence of Realistic Mathematics Education (RME) Approach Based on Mandailing Culture on Student Self-Regulated Learning in Class V of Islamic Elementary School Sihadabuan Padang sidimpuan
}

\author{
Khotna Sofiyah \\ Basic Education Study Program, \\ Postgraduate School \\ Universitas Negeri Medan \\ Medan, Indonesia \\ E-mail: khotna.sofia@yahoo.com
}

\author{
Edy Surya \\ Lecturer of Postgraduate School \\ Universitas Negeri Medan \\ Medan, Indonesia
}

\author{
Zulkifli Matondang \\ Lecturer of Postgraduate School \\ Universitas Negeri Medan \\ Medan, Indonesia
}

\begin{abstract}
This study aimed to determine whether the influence of the Realistic Mathematics Education (RME) approach based on Mandailing culture is better than ordinary learning on student self-regulated learning. This research is a quasi-experimental study. The population in this study were all students of $\mathbf{V}$ grade of Islamic Elementary School Sihadabuan Padangsidimpuan and the sample was students of VB class of Islamic Elementary School Sihadabuan Padangsidimpuan as the experimental class and VA class students of Islamic Elementary School Sihadabuan Padangsidimpuan as the control class. The instrument used is the scale of student self-regulated learning. Data analysis was performed by Mann-Whitney Test. The results of this study indicated that the RME approach based on Mandailing culture has a better effect than ordinary learning on student self-regulated learning, with Asymp value, Sig. (2-tailed) is $0,000<0,05$ and Mean Rank which is 41,86 $>25,14$.
\end{abstract}

Keywords - Self-Regulated Learning, Realistic Mathematics Education (RME) Approach, Mandailing Culture

\section{INTRODUCTION}

Education is a foundation to prepare for improving the quality of competent, independent, cultured, fearful and reliable Human Resources in order to respond to the global changes that are sweeping the world. The success of education in the school environment can be known based on the presence or absence of student self-regulated learning, especially in mathematics learning.

Student self-regulated learning in mathematics is an important part that supports the success of student learning. According to Zimmerman, et al. [1] in mathematics in particular, self-regulated learning is related to academic achievement because it affects the actual learning process. The statement was supported by Al-Mutawah [1] says that selfregulated was the key to the success of learning mathematics and science. Thus, based on one of the educational objectives stated in the Law No. 20 of 2003, student self-regulated learning becomes one of the important things that need to be grown in students.

Self-regulated learning occurs when students become controllers or controlers of their own learning process. Similarly, Bandura [2], which says that self-regulated learning is the ability to self-regulate.

According to Pintrich, self-regulated learning is an active and constructive process in which students determine their own learning goals and try to monitor, regulate and control cognition, motivation and behavior by being guided and constrained by contextual goals and characteristics in their environment [3]. Similarly, Zimmerman [4] said that selfregulated learning is a learning process where students as learners use self-regulating skills, such as self-assessment, self-direction, control and adjustment, to gain knowledge. Thus, self-regulated learning is needed so that students have a sense of responsibility to regulate and discipline themselves and develop learning skills on their own accord.

Students with independence skills learn to know when and how students protect themselves from interference that interferes with the learning process. Students with good selfregulated learning know how to overcome themselves when they feel sleepy and lazy. This is in line with the statement of Cornow, Snow and Jackson, which says that students who have good self-regulated learning, know how to protect themselves from interference that can interfere with the learning process [1].

Students who have high independence are able to deal with all problems because independent students do not depend on others, but they will always try to deal with and solve their own problems. Independence shows the belief in an 
individual's ability to solve the problem without the help of others without being controlled by others [5].

The results of the study by Lei and his research fellows said that "high achievers" self-regulation ability was higher than that of low achievers "[4]. This was also proven by Sunarsih in his research which concluded that self-regulated learning has a positive and significant relationship to learning achievement so that students who have self-regulated learning will have higher learning achievement than students who do not have self-regulated learning [6]. Students who have high self-regulated learning tend to learn better, are able to monitor, evaluate and manage their learning effectively, save time in completing their tasks, manage learning and time efficiently.

Based on the explanation above, as for indicators of student self-regulated learning in this study, namely: (1) Not dependent on others, (2) Responsible, (3) Motivation and (4) Confidence.

But in reality in the field, one of the teachers at Islamic Elementary School Sihadabuan Padangsidimpuan raised the problem of student independence in school seen from the unpreparedness of students while attending the lesson, including many students who were unable to solve real problems in daily life given independently by teachers, students often times waiting for an answer from the teacher to solve the problem, and the students were not sure of the answer during the exam and more dominantly cheated and asked the answer of his friend. Based on these problems it can be seen that student learning independence is still low.

The above problems are in line with the preliminary study Iin Suhartini, et al. [7] says that most students could not become independent learners, for example the lack of preparation for students before facing learning in class, students only learn if the exam will be carried out, students will have difficulty solving problems if given problems related to real life that were not previously given examples of the same form and students are more dominant in cheating on the work of their friends when asked to come forward to the class working on the questions.

The fact shows that so far and almost all levels of practice education in the learning process that takes place generally still use ordinary learning or one-way learning, namely the teacher as a teacher centered. This is in line with Maulydia's research, et al. which states that, "The teacher still used the usual learning form, namely explain with little interaction to give the example of question and then give the exercises. It could make the students become unusual to solve the problem with their own finishing"'[8].

Based on that, Marchis says "This method of teaching mathematics does not promote the development of mathematical thinking, problem solving skills and selfregulation learning. Teachers should be aware that they should use teaching methods and strategies with developing pupils' problem solving and self-regulation learning skills "[9].

Related to the problems presented, the teacher must design a classroom environment with models, approaches and methods that are appropriate to the characteristics of students. The learning process in the classroom should be able to foster the courage, motivation, responsibility and confidence of students to contribute in it. One approach that can overcome the above problems is RME approach, because one of its characteristics is to appreciate student contributions and to have the principles of self-developed models (the models are built by students themselves).

Approach Theory RME was first introduced and developed in the Netherlands in 1970 by the Freudenthal Institute. Based on Freudenthal's view, mathematics is a human activity [10]. Corresponedenly, Gravemeijer argues that the concept of a realistic approach is characterized by the activities of students to rediscover mathematics under the guidance of adults [11]. In the RME approach, mathematics is presented as a process of human activity, not as a finished product, but students must build their own knowledge through the settlement of contextual problems that are presented formally or informally by themselves or with the help of others.

According to Dhoruri, RME is one of the learning approaches that can enable and condition students to build their own knowledge by using models developed by the students themselves [12]. In the RME approach, students can solve a problem of mathematical problems either independently or in groups that can provide more meaningful learning outcomes so that their knowledge and learning experience will be embedded for a long time.

Sirate said that, mathematics obtained at school does not match the way of life of the local community, so mathematics is difficult to understand by students [13]. According to Rohaeti, "so that students feel that the material they are learning in mathematics is part of themselves, then mathematics learning must begin with contextual learning from the culture in which students are located" [14]. Thus, culture-based mathematics learning can make a significant contribution to the learning of mathematics in schools.

Suyitno said that, "mathematics has a relationship with the real world and the local cultures"[15]. Schoenfield stated that: "The world of mathematics culture" will encourage students to think about mathematics as an integral part of everyday life, improve students' skills in making or doing linkages between mathematics concepts in different contexts, and building understanding in the student environment by Problem solving either independently or together "[15]. Therefore, mathematics learning in schools using the RME approach is expected to be able to help students understand the material provided by the integration of the culture of the students.

The culture that will be applied in this research is the Mandailing culture. A lot of mathematical material can be associated with Mandailing culture, such as addition and subtraction of fractions. Salak, lemang, kipang and so on are the results of Mandailing culture which can be used as media or props in the learning of mathematics. When the teacher presents the material, indirectly students will be introduced with Mandailing culture itself.

Based on this, the RME approach based on Mandailing culture is a mathematical learning approach that utilizes reality and the environment that students can understand to facilitate 
the learning process by integrating the Mandailing culture into mathematics subject matter.

The success of integrating cultural values in mathematics learning can be seen from the previous research conducted by Sinaga concluding that culture-based mathematics learning can improve the effectiveness of mathematics learning in certain areas [16]. Even Uloko and Imoko in his research suggested that Japan and China succeeded in mathematics because they used mathematics based on local culture [14]. Thus, mathematics learning is very suitable if integrated with local students' cultural concepts.

Based on the background of the problem, the problem to be examined is, "does the influence of the RME approach based on Mandailing culture be better than ordinary learning on student learning?"

\section{METHOD}

This type of research is quasi-experimental research. This research was carried out at Islamic Elementary School Sihadabuan Padangsidimpublan. The population in this study were all students of $\mathrm{V}$ class of Islamic Elementary School Sihadabuan Padangsidimpuan. The collection of sampel by cluster sampling technique, where the VB class is an experimental class with the RME approach based on Mandailing culture and VA class as a control class with ordinary learning. This study uses a pretest posttest control group design.

Information:

$$
\begin{array}{cccc}
\text { Experiment } & \mathrm{T}_{1} & \mathrm{X} & \mathrm{T}_{2} \\
\text { Control } & \mathrm{T}_{1} & - & \mathrm{T}_{2}
\end{array}
$$

X : RME Approach Based on Mandailing Culture

- $\quad$ : Ordinary Learning

$\mathrm{T}_{1} \quad$ : Pretest

$\mathrm{T}_{2} \quad$ : Posttest

Data collection instruments used student self-regulated learning scale. Calculation of the validity and reliability of the instrument was tried out to students as many as 30 people. The results of the student self-regulated learning scale trial were valid as many as 30 items with a reliability coefficient of 0.76 (high interpretation). Data analysis techniques used descriptive statistics and inferential statistics. Hypothesis testing was done using the Mann-Whitney Test with the help of SPSS 20.0. The hypothesis to be tested, namely:

Research Hypothesis:

The influence of the RME approach based on Mandailing culture is better than ordinary learning on student selfregulated learning.

Statistical Hypothesis:

$\mathrm{H}_{0}: \mu_{k 1} \leq \mu_{k 2}$

$\mathrm{H}_{\mathrm{a}}: \mu_{k 1}>\mu_{k 2}$

Information: $\mu_{k 1}$ : The average self-regulated learning of students who obtain the RME approach based on Mandailing culture.

$\mu_{k 2}$ : The average self-regulated learning of students who get ordinary learning.

\section{RESULTS AND DISCUSSION}

Scale analysis of student self-regulated learning was done twice, namely pretest and posttest with questions that are equivalent statement items. Quantitatively, the results of pretest and posttest student self-regulated learning in the experimental and control classes can be seen in Table 1 .

TABLE 1. Results of Students' Pretest and Postest Self-Regulated Learning

\begin{tabular}{|c|l|c|c|c|c|}
\hline \multirow{2}{*}{ No } & \multirow{2}{*}{ Category } & \multicolumn{2}{|c|}{ Experiment } & \multicolumn{2}{c|}{ Control } \\
\cline { 3 - 6 } & Pretest & Postest & Pretest & Posttest \\
\hline 1 & Very High & 0 & 4 & 0 & 0 \\
\hline 2 & High & 5 & 13 & 0 & 6 \\
\hline 3 & Medium & 13 & 16 & 22 & 25 \\
\hline 4 & Low & 15 & 0 & 11 & 2 \\
\hline 5 & Very Low & 0 & 0 & 0 & 0 \\
\hline \multicolumn{2}{|l}{ Mean } & 78,97 & 97,45 & 76,18 & 84,88 \\
\hline
\end{tabular}

In Table 1. it can be seen the results of the students' selfregulated learning in the experimental class, that there are no students whose self-regulated learning gets very high and very low categories, as many as 5 students got a high category, as many as 13 students got a medium category and as many as 15 students got a low category. After being given a RME approach based on Mandailing culture, students were given a posttest of student self-regulated learning. In the table can be seen the results of student self-regulated learning posttest in the experimental class, that as many as 4 students whose selfregulated learning obtained a very high category, as many as 13 students whose self-regulated learning gained a high category, as many as 16 students received the medium category, and no students received a low category and very low. It is seen that the increase in the number of students in the criterion of student independence was very high. This showed that the effect of the RME approach based on Mandailing culture was better on student self-regulated learning.

In Table 1. it can be seen the results of the students' selfregulated learning the control class, that there was no student whose self-regulated learning gets very high, high and very low categories, as many as 22 students got the medium category and as many as 11 students got the low category. After being given regular learning, students are given posttest of student self-regulated learning. In the table can be seen the results of the students' self-regulated learning in the control class, that there are no students whose self-regulated learning got very high and very low categories, as many as 6 students whose self-regulated learning had a high category, as many as 25 students got the medium category and as many as 2 students got the category low. It was seen that the increase in the number of students in the criterion of student independence was very high, but not so much better. This 
showed that the effect of ordinary learning is not better on student self-regulated learning.

In Table 1. It can be seen the average value of the pretest and posttest results of the self-regulated learning of the experimental class students increased by 18,48 . The average score of the pretest and posttest resulted of the control of the learning of control class students has increased by 8,7. This showed that there are differences in pretest and posttest results of students' self-regulated learning scale in the experimental class and control class. The difference in the increase in the average score of the pretest and posttest results of the students self-regulated learning scale in the experimental class was higher than the increase in the average score of the pretest and posttest results of the students' self-regulated learning scale in the control class with a difference of 9,78.

The scale of student self-regulated learning is ordinal data and data comes from populations that are not normally distributed. Thus the statistical test used is the non-parametric statistical Mann-Whitney test.

The difference in the increase in the average score of the pretest and posttest results of the students self-regulated learning scale in the experimental class and the control class can be seen from the Mean Rank and the Significant Value. By using the help of the SPSS 20.0 program, the MannWhitney test statistics can be seen in the following Table 2 and Table 3.

TABLE 2. The Average Pretest Test Results of Student Self-Regulated Learning Ranks

\begin{tabular}{|c|c|r|r|r|}
\hline & Kelas & N & Mean Rank & Sum of Ranks \\
\hline \multirow{2}{*}{ angket } & Eksperimen & 33 & 34,92 & 1152,50 \\
& & & & \\
& Kontrol & 33 & 32,08 & 1058,50 \\
& Total & 66 & & \\
\hline
\end{tabular}

TABLE 3. Mann-Whitney Pretest Test Results for Experimental Classes and Control Classes

Test Statistics ${ }^{\mathrm{a}}$

\begin{tabular}{|l|r|}
\hline & questionnair \\
\hline Mann-Whitney U & e \\
Wilcoxon W & 497,500 \\
Z & 1058,500 \\
Asymp. Sig. (2-tailed) &,- 605 \\
a. Grouping Variable: Class &, 545 \\
\hline
\end{tabular}

In Table 3 can be seen the results of statistical tests with Mann-Whitney above it is known that the value of Asymp, Sig. (2-tailed) of 0.545 greater than the probability value $(\alpha=$ 0.05 ), so that the probability $>0.05$, it can be concluded that $\mathrm{H}_{0}$ is accepted which means pretest on the scale of student selfregulated learning between the experimental class and the control class.
TABLE 4. The Average Posttest Test Results of Student Self-Regulated Learning

Ranks

\begin{tabular}{|r|c|r|r|r|}
\hline & Kelas & N & Mean Rank & Sum of Ranks \\
\hline \multirow{2}{*}{ Angket } & Eksperimen & 33 & 41,86 & 1381,50 \\
& & & & \\
& Kontrol & 33 & 25,14 & 829,50 \\
& Total & 66 & & \\
\hline
\end{tabular}

TABLE 5. Mann-Whitney Posttest Test Results for Experimental Classes and Control Classes

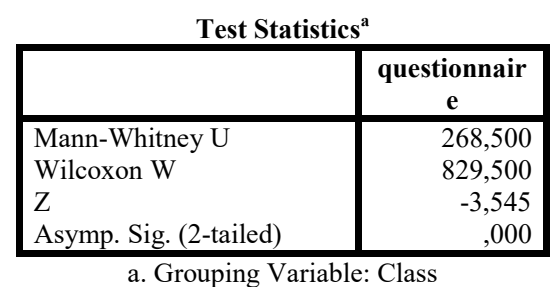

In Table 5 can be seen the results of statistical tests with Mann-Whitney above it was known that the value of Asymp, Sig. (2-tailed) equal to $0,000<0.05$. When viewed from the Mean Rank of each class, in Table 4 can be seen the Mean Rank of experimental class is greater than the control class, which is $41,86>25,14$. Thus $\mathrm{H}_{0}$ is reject which means posttest on the scale of student self-regulated learning between the experimental class and the control class was different. It can be concluded that there were differences in the posttest results of the students self-regulated learning scale of the fifth grade students taught by the RME approach based on Mandailing culture with ordinary learning. Because of the significant differences, the formulation of the research problem was answered, namely the influence of the RME approach based on Mandailing culture was better than the usual learning of student self-regulated learning.

\section{CONCLUSION}

Based on the results of the analysis and discussion of the study it can be concluded that, namely:

1. The average pretest and posttest results of student selfregulated learning given the RME approach based on Mandailing culture has increased by 18.48 from 78.97 to 97.45.

2. The effect of the RME approach based on Mandailing culture is better than ordinary learning on student selfregulated learning. This is indicated by the Asymp value, Sig. $<0.05(0.000<0.05)$ with Mean Rank which is $41,86>$ 25,14 . 


\section{ACKNOWLEDGMENT}

Thank you, the writer, for the supervisors who have provided direction for the improvement of this research. The author also thanked to the Rector and Director of Postgraduate School of State University of Medan. Thanks also to the headmaster of Islamic Elementary School Sihadabuan Padangsidimpuan, the teachers, students and friends involved in this research.

\section{REFERENCES}

[1] Al Mutawah, M.A., Thomas, R. \& Khine, M.S., "Investigation into Selfregulation, Engagement in Learning Mathematics and Science and Achievement Among Bahrain Secondary School Students. IEJMEMathematics Education, Vol. 12, No. 6, hlm 633-653.

[2] Tjalla, A. dan Sofiah, E., "Effect of Methods of Learning and Self Regulated Learning toward Outcomes of Learning Social Studies", Journal of Education and Practice, Vol. 6, No. 23, 2015, hlm 15-20.

[3] Alotaibi, K., Tohmaz, R. \& Jabak, O., "The Relationship Between SelfRegulated Learning and Academic Achievement for a Sample of Community College Students at King Saud University, SciencePG, Vol. 6, No.1, 2017, hlm 28-37.

[4] Cheng, Eric C.K, "The Role of Self-Regulated Learning in Enhancing Learning Performance", Time Tylor International, Vol. 6, Issue 1, 2011 hlm 1-16.

[5] Kurniawati, "Hubungan Antara Efikasi Diri dengan Kemandirian Belajar Siswa Kelas V SD Negeri Se-Kecamatan Srandakan", Jurnal Pendidikan Guru Sekolah Dasar, Edisi 23 Tahun Ke-5, 2016, hlm. 2197-2208.

[6] Hatiningtyas, dkk., "Hubungan Antara Self Regulated Learning dan Locus Of Control Internal dengan Kematangan Vokasional Siswa SMK", Jurnal Pendidikan: Teori Penelitian dan Pengembangan, Vol. 1, No. 6, 2016, hlm 1127-1136.

[7] Suhartini, I., Syahputra, E., \& Surya, E., "Pengthat the probability $<0.05$, it can be concluded that $\mathrm{HO}$ is rejearuh Pembelajaran
Kontekstual Terhadap Kemampuan Pemecahan Masalah Matematik dan Kemandirian Belajar Siswa di MTs Miftahussalam Medan", Jurnal Paradikma, Vol. 9, No.3, 2016, hlm 62-71.

[8] Maulydia, S. S., Surya, E., \& Syahputra, Edi, "The Development of Mathematic Teaching Material Through Realistic Mathematics education to Increase Mathematical Problem solving of Junior High School Students". International Journal Of Advance Research And Innovative Ideas In Education (IJARIIE), Vol-3, Issue-2, 2017, hlm 2965-2971.

[9] Marchis, I, "How Mathematics Teachers Develop Their Pupils' SelfRegulated Learning Skills". Acta Didactica Napocensia, Vol. 4, No. 2-3. 2011

[10] Heuvel-Panhuizen, M.V.D. The Didactical Use of Models in Realistic Mathematics Education: An Example from A Longitudinal Trajectory on Percentage. Educational Studies in Mathematics, Vol. 54, 2003, hlm 9-35. Kluwer Academic Publisher. Printed in the Netherlands.

[11] Lestari, L. \& Surya E, "The Effectiveness of Realistic Mathematics Education Approach on Ability of Students' Mathematical Concept Understanding", International Journal of Sciences: Basic and Applied Research (IJSBAR), Vol. 34, No 1, 2017, hlm 91-100.

[12] Mesarius, G. \& Surya, E, "Improve Learning Outcomes of Comparing Fractions by using the Realistic Mathematical Learning Approach in Class III of Public Primary School 040457 of Berastagi”, IJSBAR, Vol. 34, No.1, 2017, pp. 166-174.

[13] Sirate, F.S. 2012. Implementasi Etnomatika dalam Pembelajaran Matematika pada Jenjang Pendidikan Sekolah Dasar. Jurnal Lentera Pendidikan, Vol.15, No.1, hlm 41-45.

[14] Rohaeti, E., "Transformasi Budaya Melalui Pembelajaran Matematika Bermakna" Jurnal Pengajaran MIPA UPI Bandung, Vol.16, No.1, 2011, hlm 139-147.

[15] Zaenuri, Suyitno, H., Rokhman, F. \& Suyitno, A., "Developing of Supplementary Books of Mathematics Teaching-Learning Process Based-on Coastal Culture for JHS Students". IEJME-Mathematics Education, Vol. 12, No.4, 2017, hlm 421-430.

[16] Sinaga, B., "Pengembangan Model Pembelajaran Matematika Berdasarkan Masalah Berbasis Budaya Batak (PBM-B3). Disertasi. Surabaya: Program Pascasarjana Universitas Negeri Surabaya. 2007. 